\title{
POLA-POLA GERAK PADA TOPENG BARONGAN KERTAS SEBAGAI INOVASI PENGEMBANGAN TRADISI KERAKYATAN
}

\author{
Oleh: \\ Karyono, S.Kar., M.Sn. \\ Tubagus Mulyadi, S.Kar., M.Sn.
}

\begin{abstract}
Barongan Blora is one of the communal arts that developed in the Blora, Rembang and Grobogan areas. Barongan dish was originally a spiritual form of its presence, not paying attention to the aesthetic elements more focused on its function. Barongan movement patterns cannot be separated from the Barong mask which has been made from wood which is the shape of a large mask. This greatly affects the patterns of movement in the Barong dance. The innovation of the Barongan mask as a form of developing a populist tradition has an alternative in making masks made from paper. This is done to get the possibility of movement patterns related to the development of innovation in the Barong populist arts tradition. The creative engineering effort of the Barongan mask by utilizing waste paper becomes an alternative to enrich the work of dance moves related to the lighter mask properties as a large mask performance. Replacing wood media with paper in mask making. With the hope of facilitating the game techniques in accordance with the character of Barong and silat movements as if kanuragan. The purpose of this study is to look for basic concepts about Barongan movement patterns that are technically related to paper mask media. The research method used is rise up by practice, the artistic method, the creation of art based on research. The results of the study showed that the movement patterns were worked on as the basis for developing the Barongan Kertas mask dance. Research outputs targeted at this study are; Intellectual Property Rights and National Journal.
\end{abstract}

Keywords: Paper Bar, Innovation, Popular Traditions.

\section{PENDAHULUAN}

\section{Latar Belakang}

Seni memiliki banyak keunggulan berupa peningkatan kehalusan budi pekerti, peneguhan karakter bangsa, dan untuk mengangkat nilai kompetitifbangsa Indonesia dalam percaturan diplomasi internasional. Penciptaan dan penyajian seni berbasis nilai-nilai lokal dan nasional mampu membawa kekhasan dalam pementasan. Lunturnya kebanggaan dan rasa nasionalisme memprihatinkan dengan munculnya berbagai radikalisme dan budaya asing yang tidak berkepribadian Pancasila, maka perlu adanya penelitian sebagai dasar inovasi terhadap seni tradisi terutama pada seni kerakyatan yang kental dengan lokal jenius. Seni lokalyang beragam dari berbagai daerah dapatmerekatkan kebhinekaan yang menjadi motifasi terhadap rasa kebangsaan dan NKRI. Pembentukan sikap kebangsaan dan bangga terhadap tanah air diawali dengan rasa cinta kepada budaya sendiri.

Barongan Blora merupakan salah satu seni rakyatsebagai bentuk budaya komunal masyarakat Blora yang berisi nilai-nilai keraifan lokal. Barongan merupakan genre pertunjukan topeng. Sebagai suatu pertunjukan yang menggunakan topeng memiliki latar belakang keterkaitan dengan ritual masyarakat. Bentuk topeng Barongan mirip dengan kepala harimau (felistigris), muka dan mulut besar, diberi kain atau bagor untuk badannya yang dikenakan oleh penari, sehingga mirip dengan binatang besar (Slamet,2011:1). Di Blora wujudnya mirip dengan singa, bagimasyarakat Blora perwujudan Barongan lebih identik dengan harimau, maka kain penutup badan dibuat loreng seperti kulit harimau. Hal yang sedemikian rupa juga terjadi pada masyarakat sekitar Blora termasuk Rembang dan Purwodadi yang mempunyai kesamaan budaya dalam wilayahnya.

Barongan merupakan salah satu kesenian rakyat yang amat popular di kalangan masyarakat Blora, terutama masyarakat pedesaan. Didalam Barongan tercermin sifat-sifat kerakyatan masyarakat Blora, seperti sifat: spontanitas, kekeluargaan, kesederhanaan, kasar, keras, kompak, dan keberanian yang dilandasi kebenaran (Slamet: wawancara tanggal 23 Mei 2019.

Penguasaan terhadap seni tradisi perlu adanya konservasi dan preservasi yaitu sebuah penggarapan dengan inovasi tanpa meninggalkan tradisi, maka terjadi suatu pemeliharaan budaya. Pola-pola gerak Barong selama ini terkait dengan media topeng Barongan yang terbuat dari kayu 
memiliki berat yang menjadikan terbatasnya gerak. Hal ini yang menjadikan minimnya vokabuler gerak tari Barong.

Topeng Barongan kertas sangat tepat dalam pencarian pola-pola gerak tari Barong sebagai dasar penggarapan tarian Barongan.

Spesifikasi khusus dalam skema ini adalah penemuan pola-pola gerak tari Barong sebagai inovasi pengembangan tradisi kerakyatan. Konsep garap Barongini memberiinovasi dan sekaligus pemeliharaan seni BarongBlora kedalam model tari Baronggarap seni pertunjukan. Maka pola-pola gerak Barongan kertas sebagai bentuk pengkayaan vokabuler serta pola-pola dasar sebagai pijakan gerak tari Barongan Blora. Mengkaji permasalahan di atas sebagai dasar pencarian pola-pola gerak tari Barong dalam inovasi pengembangan tradisi kerakyatan. Maka rumusan masalahnya adalah sebagai berikut.

1. Mengapa perlu dicari pola-pola gerak sebagai dasar pijakan gerak tari Barong?

2. Bagaimana proses dan pembentukan pola-pola dasar gerak tari Barong kertas?

\section{Tujuan dan Urgensi Penelitian}

Tujuan penelitian ini adalah untuk mencari konsep dasar tentang pola-pola gerak Barongan yang secara teknik terkait dengan media topeng kertas.

\section{Mendeskripsikan dan menganalisis proses} pembentukan pola-pola dasar gerak tari Barong kertas.

Bermula dari penelitian Karyono pada hibah bersaing DRPM dan penelitian-penelitian yang dilakukan oleh Slamet pada tahun 2011 serta pengamatan peneliti terhadap Barongan Blora. Ternyata Barongan mendapat perhatian masyarakat Blora sehingga Barongan menjadi seni komunal bahkan merupakan ikon Blora.

Hasil temuan masalah tentang prosesi garap seni pertunjukan dalam Barongan. Guna mendukung kerangka berpikir dan studi awal dilakukan studi pustaka terhadap berbagai tulisan dengan masalah yang akan diteliti. Adapun bukubukuyangterkaitsebagai berikut.

"Barongan Menari diatas Politik dan Terpaan Jaman oleh Slamet, tahun2012 berisi tentang Barongan sebagai seni identitas Blora, serta pengaruh perkembangan politik, sosial, dan ekonomi terhadap pertunjukan Barongan. Tulisan ini banyak memberiinformasi tentang bentuk- bentuk pertunjukan Barongan di Blora terkait dengan propaganda politik dan pengaruh perubahan sosial serta dampak perkembangan ekonomi menuju pada pertunjukan Barongan Panggung. Model pertunjukan Barongan Panggung ini memberikan kerangka berpikir sebagai pijakan Barong sebagai Garap Seni Pertunjukan yang kekinian dan mudah diterima masyarakat skala nasional. Dengan demikian penelitian ini yang hasilakhirnya berupa konsep polapola dasar gerak tari Barong.

"Model Pertunjukan Barongan Anak" laporan Penelitian Karyono dibiayai Hibah Bersaing DRPM Diktitahun 2012 berisi tentang model Barongan untuk anak. Peneliti terfokus pada konsep dan model Barongan untuk anak. Lebih lanjut diterangkan dalam tulisan ini berdasar pada telusur yang dilakukan dalam pertunjukan Barongan di Blora lebih didominasi pada Barongan untuk orang dewasa. Maka tulisan ini mencari format dan model pertunjukan untuk anak. Penelitian ini juga memberi penjelasan tentang system pembelajaran Barongan yang dilakukan disekolah-sekolah. Penelitian tentang BarongGarap Seni Pertunjukan merupakan sebuah korelasi antara garap-garap Barongansebelumnya. Penempatan Barong Garap Seni Pertunjukan berkedudukan sebagai wujud ekspresi masyarakat pemilik kesenian terhadap budaya lokalyang diangkat sebagai sebuah garap seni pertunjukan dengan skala nasional. Sehingga Barong Garap Seni Pertunjukan kedudukannya merupakan penelitian yang masih orisinil.

\section{Bagan Alir Penelitian}

Penelitian Pola-Pola Dasar Gerak Barongan Sebagai Inovasi Pengembangan Tradisi Kerakyatan, disajikan dalam bagan alur sebagai berikut.

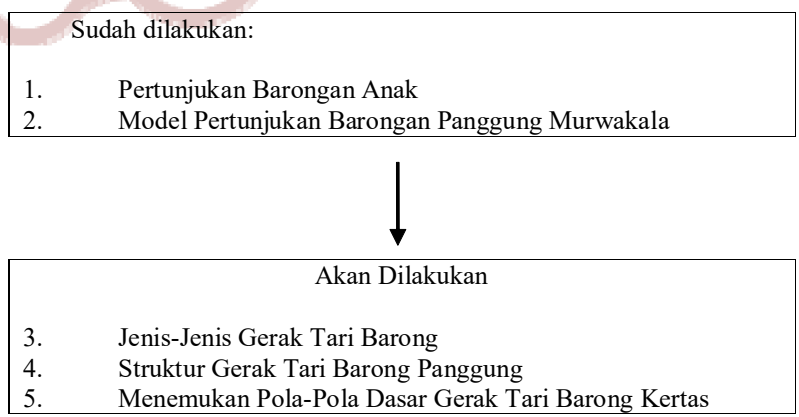

Penelitian Dasar Pola-Pola Gerak Tari Barong Kertas Sebagai Inovasi Pengembangan Tradisi Kerakyatan. Penelitian ini menekankan pada konsep pola-pola dasar gerak Barong melalui eksplorasi dan eksperimen yang sebelumnya dilakukan observasi untuk mendapatkan gambaran-gambaran tentang tarian Barong Blora. Penelitian ini juga tidak luput 
dengan studi pustaka sebagai bentuk kegiatan akademis dalam memperoleh referensi terkait dengan objek penelitian. Adapun proses penemuam pola-pola gerak diawali dengan melihat dan mencoba gerakgerak yang telah ada terkait dengan media kayu pada topeng Barongan. Temuan dari observasi diolah dan dianalisis dalam sebuah bentuk eksperimen dengan menggunakan topeng Barongan kertas. Hasil eksperimen dilakukan sebuah pembentukan upaya menemukan pola-pola gerak tari dengan property topeng Barongan media kertas. Hasil eksperimen merupakan pembentukan pola-pola gerak tarian dengan property topeng Barongan media kertas sebagai dasar pijakan pada pengembangan tari Barongan lebih lanjut. Adapun teknik pengumpulan data sebagai berikut.

\section{Observasi}

Observasi dilakukan pada pengamatan tari Barong. Pengamatan tari Barong pada tiga daerah hal ini untuk mendapatkan jawaban tentang permasalahan terutama pada pola-pola dasar gerak tari Barongan.

2. Wawancara

Wawancara dilakukan pada tiga lokasi penelitian dengan memperhatikan pengalaman-pengalaman mereka tentang pola-pola dasar teknik gerak Barongan. Apabila dalam pengamatan perlu adanya verifikasi khusus pada nara sumber maka dilakukan sebuah wawancara sebagai verifikasi data. Adapun nara sumber yang dimaksud adalah.

(1). Gajug seorang seniman Barongan dari daerah Tegal Gunung Kota Blora. Dari wawancara yang didapat informasi tentang penggunaan topeng Barongan.

(2). Kukuh seorang seniman Barongan dari daerah Ngawen Blora, wawancara ini mendapatkan informasi sesuai dengan tofik yang diteliti.

(3). Muchsin seorang seniman Barongan dari Desa Kunduran Kabupaten Blora. wawancara ini mendapatkan pengetahuan tentang teknikdasar penggunaan topeng Barongan kertas.

\section{Analisis Penelitian Dasar}

Penelitian ini menghasilkan konseptual secara tertulis dengan menemukan pola-pola gerak dasar Barongan sebagai pijakan pengembangan inovasi tradisi kerakyatan. Analisis dilakukan pertama kali mengamati dari berbagai pertunjukan Barongan kemudian mengembangkan dan mencari kemungkinan lain terkait dengan property media Barong kertas. Hasil yang didapat dari amatan kemudian dicoba kemungkinan teknik-teknik gerak baru tentu terkait dengan media topeng Barongan. Penelitian Dasar ini pada awalnya dilakukan pembuatan topeng Barongan dari kertas dengan tidak menghilangkan karakter dan bentuknya. Maksud dari pembuatan Barongan topeng kertas untuk mencari bentuk teknik terkait dengan polapola dasar gerak Barong sebagai wujud pertunjukan panggung lebih menekankan pada estetika gerak.

4. Lokasi Penelitian;

Lokasi penelitaian di wilayah Blora, Rembang, dan Purwodadi

5 Pendekatan ini menggunakan pendekatan Etnokoreologi menekan pada penelitian tarian etnis non Barat dengan menerapkan pola-pola penelitian Etnografi. Penelitian Etnografi sangat tepat diterapkan pada penelitian tari tradisi kerakyatan dengan melihat atau mengamati fenomena objek yang diteliti. Hasil pengamatan dibawa kelaboratorium kemudian dikembalikan lagi kelapangan untuk ferifikasi data. Selanjutnya hasil ferifikasi dibawa kelaboratorium untuk dilakukan sajian data denganpresentasi grafis yang dimaksud hal ini adalah berupa gambar-gambar dan notasi tari bila diperlukan.

6. Luaran Penelitian

Luaran penelitian yang ditargetkan, yaitu: (1) HKI, (2) Artikel Jurnal Nasional Terakreditasi

7. Indikator Capaian ditemukannya Pola-pola Dasar Gerak Tari Barong sebagai inovasi pengembangan tradisi yang selanjutnya dipakai sebagai pijakan dalam garap tari Barong Blora.

\section{PEMBAHASAN}

\section{Pola-Pola Baku Gerak Barongan Kertas}

Model Topeng Barongan Kertas

Barongan merupakan topeng besar yang menggambarkan Harimau, di Blora Barongan dipercaya sebagai binatang Tottem yang dianggap dapat melindungi (magi protektiv). Topeng Barongan pada awalnya hanya sebagai sarana untuk mendatangkan roh binatang tottem. Perkembangan selanjutnya Barongan menjadi sebuah pertunjukan, namun kehadirannya tetap memiliki magi atau disakralkan. Melihat hal ini tidak jarang topeng Barongan dibuat seram dan memilikikesan magis. Topeng Barongan di Blora dalam pembuatannya memiliki aturan atau hal-hal yang selalu dilakukan setiap pembuatan topeng. Bahan topeng Barongan 
juga memilih kayu khusus seperti kayu dadap. Pemilihan kayu dadap sebagai bahan karena kayu Dadap dianggap memiliki unsur religi. Pemilihannya pun biasanya dicari kayu dadap yang tumbuh ditepi sungai disebelah timur sungai. Selain itu pengrajin dalam pembuatan topeng melakukan ritual khusus seperti berpuasa, mencari hari dalam memulai pembuatan topeng dan bisanya meminta ijin pada punden setempat.

Topeng Barongan di Blora memiliki kekuatan khusus, hal ini kebiasaan masyarakat Blora untuk melihat dan membuktikan topeng Barongan pada kelompok tertentu memiliki suatu kekuatan diadakan sebuah lomba dengan mengadu topeng Barongan yang dikenal dengan Barongan gaprak. Adu Barongan ini sangat digemari masyarakat Blora dan dinanti-nanti, karena melalui adu Barongan ini menjadikan suatu grup terkenal dengan kekuatan Barongannya. Kemenangan Barongan ditentukan dari kekuatan topeng. Ada suatu peristiwa yang menarik pada Barongan gaprak belum sampai menyentuh antar topeng, topeng sudah pecah. Kemenangan dari Barongan ini menjadikan grup Barongan tersebut mendapat banyak tawaran untuk pentas arak-arakan, baik itu ritual maupun even arak-arakan hari besar Nasional.

Perkembangan selanjutnya karena kebutuhan artistik bukan kekuatan menjadi penentu namun bentuk topeng Barongan serta bentuk pertunjukannya. Lombalomba tentang Barongan tidak lagi menggunakan Barongan gaprak melainkan berkembang menuju estetika bak itu topeng maupun bentuk pertunjukannya. Pada tahun 2003 dimulai festival Barongan dengan penilaian untuk tari barongan dan pertunjukannya. Barongan dari hasil lomba ternyata lebih menjamin untuk segi ekonomi pada kelompoknya karena sering ditanggap pada hajatan2 sebagai pengisi hiburan. Kenyataan ini mejadi tantangan bagi kelompok-kelompok Barongan untuk memperindah topeng Barongannya serta tampilan gerak tarinya (Wawancara, Slamet, tahun 2019).

Upaya-upaya pemerintah dalam mengoptimalisasi Barongan sebagai icon tidak berhenti pada lomba namun banyak upaya yang dilakukan seperti mengadakan pembinaan pada pengrajin topeng Barongan dan pelatihan-pelatihan tari Barongan.

Penggarapan model Barongan Panggung berpijak pada versi ceritera yang berkembang dimasyarakat Blora. Barongan yang berkembang di Blora saat ini menurut buku Barongan Blora Menari di atas Politik dan Terpaan Jaman yang di tulis oleh
Slamet dikatakan bahwa ceritera-ceritera yang membingkai pada pertunjukan Barongan merupakan ceritera Panji. Namun perlu difahami perkembangan ceritera ini diawali pada tahun 1964 dengan penggarapan Barongan Panggung oleh Parpol PNI sebagai ajang propaganda politiknya dengan menggarap ceritera seperti pada reog Ponorogo. Dasar ceritera ini mempola pada pertunjukan Barongan saat ini (Slamet, 2014: 56). Perkembangan Barongan yang mengalami perjalanan pada awalnya lebih difungsikan sebagai sarana tolak bala terkait dengan kepercayaan Narasima dan Buta Kasipu. Namun perjalanannya membuahkan beberapa versi ceritera menurut kepentingannya. Maka tidak mengherankan apabila Barongan memiliki keragaman versi ceritera.

Versi cerita dalam Barongan Blora memiliki beberapa versi, versi yang sering digunakan dalam pertunjukan Baronan di Blora adalah versi ceritera Panji. Versi ini terkait dengan pertunjukan topeng, pada umumnya pertunjukan topeng di Jawa memnggunakan atau berlatar belakang ceritera Panji. Berbeda dengan Barongan Murwakala. Versi ceritera yang digunakan dalam Barongan Murwakala adalah versi Batara Wisnu versus Buta Kesipu. Menururt penelitian sebelumnya yang dilakukan Slamet terkait dengan Barongan dan Genderuwon memberi kerangka pada pertunjukan Barongan, sebagaimana yang terdapat dalam upacara ritual lamporan dan ruwatan wong sukerta, diceriterakan sebagai berikut.

...di lereng gunung Kendeng berdiam raksasa yang bernama Buta Kesipu. Warga di sekitar gunung Kendeng termasuk Blora gelisah karena ulah Buta Kesipu yang sering memangsa ternak peliharaan masyarakat sekitar dan memangsa orang-orang yang dikatagorikan wong sukerta.

Diceritakan, ketika Batara Kala meminta makanan kepada Batara Guru, ayahnya, selanjutnya Batara Guru berpesan sebelum memakan mangsanya terlebih dahulu harus dibunuh dengan senjatanya, yaitu pedang mentawa. Selanjutnya Kala berubah wujud menjadi Buta Kesipu dan minta izin untuk turun ke dunia kemudian tinggal di Gunung Kendeng.

Batara Kala setelah meninggalkan Kayangan, Batara Narada memberikan saran kepada Batara Guru bahwa manusia di dunia akan habis dimakan Batara Kala kalau tidak dicarikan jalan keluar. Atas sarannya itu maka Batara Guru meminta agar Batara Narada mencari Wisnu untuk turun ke dunia bertindak sebagai Narasima berupa Barongan.

Di Medang Kamolan $m B o k$ Brog memberitahu Belot, bahwa Belot adalah anak ontang-anting (yaitu anak yang tanpa saudara). Anak ontang-anting itu 
termasuk orang yang sukerta. mBok Brog memberi nasehat kepada anaknya agar mandi jamas (keramas) di Telaga Madirda. Atas perintah ibunya itu Belot berangkat menuju telaga. Bersamaan dengan itu Kala juga datang di telaga dan mengetahui Belot yang sedang mandi. Karena katakutan, Belot bersembunyi serta mencoba melarikan diri dari kepungan Batara Kala. Namun demikian Batara Kala terus mengejarnya, tetapi kakinya terjerat sampah bambu. Belot masuk ke dapur menyampar periuk nasi, sehingga terguling, Batara Kala terus mengikuti, kemudian Belot bersembunyi di rumah yang belum jadi, Batara Kala terus mengejarnya, karena merasa jengkel Batara Kala mengutuk pemilik rumah agar rejekinya dikurangi.

Akhirnya Belot masuk ke desa, namun Batara Kala tetap mengikuti untuk menangkapnya.Batara Wisnu menghadap Semar (Nayantaka), Gareng (Untub), menerima kedatangan Batara Narada, meminta Batara Wisnu turun ke dunia, bertindak sebagai Narasinga (Barongan). Kemudian Batara Wisnu mencari keberadaan Batara Kala yang telah menjelma menjadi Buta Kesipu.

Kegelisahan dan penderitaan masyarakat sekitar gunung Kendheng terdengar oleh Batara Wisnu, yang saat itu belum berubah wujud. Di Desa Medang Kamulan Batara Wisnu bertemu mbok Brog, di saat itu Belot anak mbok Brog sedang dikejar-kejar Buta Kesipu, maka mbok Brog meminta tolong kepada Batara Wisnu. Mendengar cerita itu Batara Wisnu meminta mbok Brog pulang menyiapkan sesaji. Batara Wisnu menolongnya, karena kesaktian Buta Kesipu yang tidak dapat dibunuh oleh manusia maupun hewan dan tidak dapat dibunuh di siang hari atau malam hari menjadikan bingung Batara Wisnu. Namun Batara Wisnu tidak kurang akal menjelmalah ia berubah menjadi Narasinga, seperti yang diperintahkan Narada, Narasinga berkepala singa (Felis leo) berbadan manusia, dan berangkatlah ia menuju kediaman Buta Kesipu tepat pada sore hari, dengan cara demikian terbunuhlah Buta Kesipu di tangan Narasinga jelmaan Batara Wisnu. Berlatar belakang cerita itu masyarakat Blora membuat topeng kepala singa (Felis leo) yang oleh masyarakat Blora diidentikkan dengan harimau (Felis tigris), sedangkan untuk Buta Kesipu dibuatlah topeng Gendruwon yaitu sosok raksasa hitam membawa pedang. Kedua tokoh ini yang selalu hadir dalam pertunjukan Barongan di Blora (Slamet, 2014:60)

Uraian di atas memberi suatu inspirasi garap baru pada Barongan Blora. Pada awalnya Barongan dimainkan oleh dua orang satu sebagai kepala Barong yang memainkan topeng, dan satunya sebagai ekor. Pertunjukan seperti ini telah berlangsung lama karena kebiasaan masyarakat. Barongan hanya digunakan pada arak-arakan. Namun sebelum arak-arakan ada atraksi tari kucingan, Barongan hanya dimainkan oleh satu orang yang menarikan topeng Barongan. Awal dari sini tergarap tari Barongan yang berkembang sampai sekarang yang hanya ditarikan oleh satu orang. Barongan Blora telah mengalami perkembangan dan inovasi baik pola gerak maupun bentuk topeng. Tetapi perlu diingat pengembangan dan inovasi harus tetap berpijak pada radisi masyarakat karena Barongan sebagai seni kerakyatan. Barongan hidup dan berkembang kareba kebiasaan atau tradisi dimasyarakat sehingga tampilan Barongan tidak lepas dari kondisi dan keinginan masyakat. Penggarapan Barongan yang ada pada saat ini yang diinisiasi oleh Slamet merupakan pengembangan yang masih tetap melihat keiasaan masyarakat yangnpertama-tama dilihat adalah pola-pola gerak dari kebiasaan masyarakat agrarais. Kemudian dalam kesempatan ini Barongan digarap dengan melihat tradisi Barongan digunakan sebagai lah kanuragan maka tidak telas daei geak-gerak bela diri. Kebiasaan masyarakat dalam olah kanuragan dalam kelompok Barongan tidak pada pertunjukan Barongannya namun terlingkup dalam sebuah pertunjukan Barongan yaitu pada beladiri Kontho. Hal ini biasanya diperagakan pada arak-arakan Barongan dan pada setiap kesempatan diadakan atraksi Kontho (pencak silat pedang).

Penelitian dengan topik Pengembangan PolaPola Gerak Tradisi Kerakyatan pada Barogan Blora dalam sebuah pertunjukan teruatama dalam garap gerak tari yang diperuntukan untuk pertunjukan Panggung. Menggarap pola-pola gerak yang bersumber pada beladiri kontho maka diperlukan topeng yang dapat digunakan untuk permainan terutama penerapan pada pola-pola gerak yang bersumber pada beladiri kontho. Topeng Barongan saat ini masih seperti Barongan terdahulu walaupun model sudah tergarap secara artistik masih tetap memiliki berat 5 - 10 kilo gram.

Pemikiran tetantang topeng Barongan terinspirasi pada topeng Barongsai yang terbuat dari kertas, maka dalam penelitian ini menggarap Barongan yang telah diinisiasi pada tahun 2018 oleh Slamet terbuatlah topeng Barongan dari Kertas dengan tidak meninggalkan bentuk dan karakter topeng Barongan Blora. Dengan terbentknya topeng Barongan kertas maka penenlitian ini beusaha mencari kemungkinankemungkinan pola-pola gerak Barongan yang 
disesuaikan dengan kondisi dan bentuk topeng Barongan kertas.

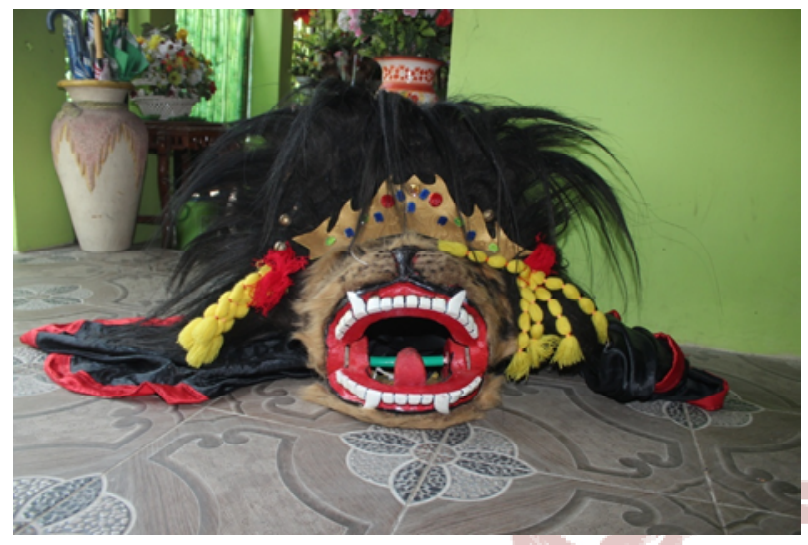

Gambar 1. Foto Barongan Kertas (dokumentasi Kartiko 15 Oktober 2019)

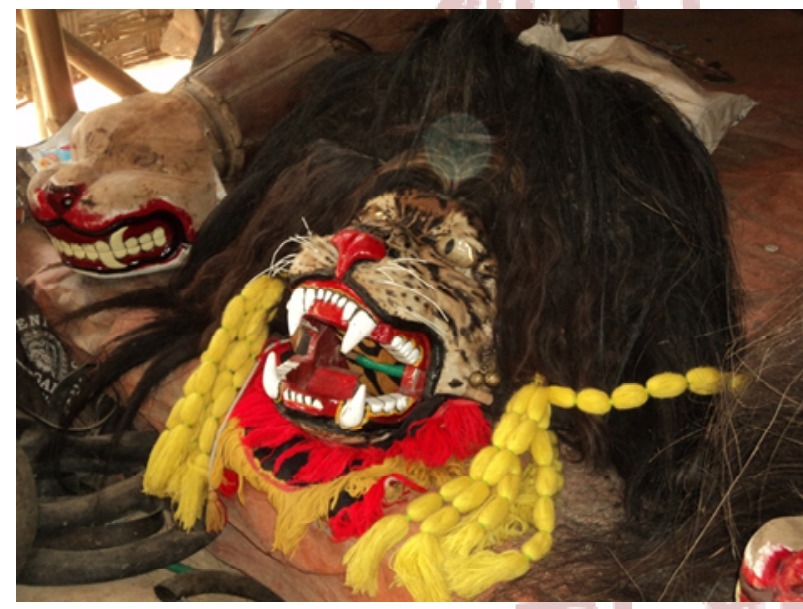

Gambar 2. Barongan Kayu (dokumentasi Tubagus Mulyadi 2016)

\section{Pola Dasar Gerak Barongan Kertas:}

Barongan Blora telah mengalami perkembangan terutama dalam pola gerak dasar yang selama ini berkembang di Blora terdiri atas gerak Kebyah, Senggot, Dadakan, Tapukan, Geteran, Dekeman, Mbkur, Sendhalan, dan Glundungan. Gerakgerak tersebut menjadipijakan Barongan dalam pertunjukannnya. Rangkaian-rangkaian gerak dalam pertunjukan Barongan berpijak pada pola-pola gerak tersebut. Pada awalnya pola-pola gerak tersebut disusun atas dasar pada tari Macanan yang biasa ditampilkan pada awal arak-arakan dan akhir arakarakan. Kemudian melihat tampilan tari macanan maka tergaraplah tari Barongan saat ini yang dipentaskan sebagai pertunjukan Panggung. Berbeda pada awalnya Barongan hanya dipertunjukkan pada acara arak-arakan. Kemudian ada upaya dipertunjukan dalam sebuah pola ceriteraatau Drama Barongan yang diawali pada tahun 1964 (wawancara; Slamet 24 September 2019).

Pola-pola yang sudah digarap sebelumnya berpijak pada pola tradisi kerakyatan yang lebih terkait dengan masyarakat penari. Hal ini diwujudkan pada nama motif gerak senggot, gebyah, dan tapuk walang. Selanjutnya penelitian pada Barongan kertas ini selain masih menampilkan pola gerak tersebut dilakukan upaya penggarapan pola-pola gerak yang mendukung dengantopeng Barongan Kertas dengan segala teknik dan permainnannya. Pola-pola gerak yang digarap dikaitkan dengan fungsi Barongpan sdebagai oleh kanuragan. Adapun pola-pola gerak diuraikan sebagai berikut.

\section{Pola-Pola Dasar Gerak Barongan Kertas}

\begin{tabular}{|c|c|c|c|c|}
\hline No & Ragam Gerak & Hitungan & Deskripsi Gerak & Keterangan \\
\hline & Sendoran Maju-Mun & $\begin{array}{l}\text { (hitungan } \\
\text { diulang } \\
\text { menurut } \\
\text { kebutuhan) }\end{array}$ & $\begin{array}{l}\text { Maju kaki kanan sudut } \\
\text { kanan,kedua tangan memegang } \\
\text { topeng ke arah sudut kanan atas } \\
\text { (nyendor). } \\
\text { Maju sudut kaki kiri, tangan } \\
\text { memegang topeng ke arah sudut } \\
\text { kiri atas (nyendor). Kemudian } \\
\text { kaki kiri mundur ke sudut kiri } \\
\text { belakang, kaki kanan diangkat } \\
\text { lutut ke arah sudut kiri depan. } \\
\text { Kedua tangan memegang topeng } \\
\text { (nyendor) ke arah bawah sudut } \\
\text { kanan depan. Kaki kanan } \\
\text { diletakan ke sudut kanan } \\
\text { belakang, kaki kiri diangkat ke } \\
\text { arah sudut kanan depan kedua } \\
\text { tangan memegang topeng } \\
\text { (nyendor) ke arah bawah kiri } \\
\text { depan. }\end{array}$ & $\begin{array}{l}\text { Foto 1. Sendoran } \\
\text { maju-mundur }\end{array}$ \\
\hline 2 & Sempokan kanan & $\begin{array}{l}\text { 5-8 } \\
\text { (Gerak } \\
\text { diulang- } \\
\text { uleng } \\
\text { bergantian } \\
\text { kanan,kiri } \\
\text { sesuai } \\
\text { kebutuhan } \\
\text { pentas). }\end{array}$ & $\begin{array}{l}\text { Jujut kaki kanan kearah } \\
\text { belakang,kaki kiri mundur } \\
\text { ke belakang shingga kedua } \\
\text { bersilangan, kedua lutut } \\
\text { ditekuk (sempok)sampai } \\
\text { duduk, topeng geter arah } \\
\text { depan.Kedua kaki gerak } \\
\text { berdiri sambil memutar } \\
\text { badang kearah kiri (setengah } \\
\text { lingkaran), kaki kiri jujut, } \\
\text { kaki kanan mundur jadi } \\
\text { silang kemudian kedua lutut } \\
\text { ditekuk menjadi posisi } \\
\text { duduk, kedua tangan } \\
\text { memegang topeng gerak } \\
\text { geter kearah depan. }\end{array}$ & \\
\hline 3 & Kirikan ogeg & $\begin{array}{c}5-8 \\
\text { (Hitungan } \\
\text { dilakukan } \\
\text { berulang- } \\
\text { ulang sesuai } \\
\text { dengan } \\
\text { kebutuhan } \\
\text { pentas) }\end{array}$ & $\begin{array}{l}\text { Kedua kaki bersilangan } \\
\text { posisi sempok kiri, badang } \\
\text { arah hadap depan, kedua } \\
\text { tangan memegang topeng } \\
\text { ke arah kanan depan, } \\
\text { Kemudian ogeg lambung } \\
\text { kanan-kiri tiga kali hitingan, } \\
\text { topeng turun kebawah } \\
\text { kearah sudut kiri depan, } \\
\text { kemudian ogeg kiri-kanan- } \\
\text { kirir, kedua tangan } \\
\text { memegang topeng arah atas } \\
\text { sudut kanan belakang. }\end{array}$ & \\
\hline 4 & Caplokan & $1-8$ & $\begin{array}{l}\text { caplokan } 3 \text { kali, tangan } \\
\text { kanan kiri digerakan ke atas } \\
\text { kebawah, posisi kaki } \\
\text { sempok kakan, badan hadap } \\
\text { samping kakan. }\end{array}$ & \\
\hline
\end{tabular}




\begin{tabular}{|c|c|c|c|}
\hline 5 & Ginjalan & $\begin{array}{l}1-8 \\
1-8\end{array}$ & $\begin{array}{l}\text { Angkat lutut kanan kearah } \\
\text { sudut kanan depan naik } \\
\text { turun } 2 \text { kali, kaki mengikuti } \\
\text { kaki kanan dibelakang, } \\
\text { kedua memegang topeng } \\
\text { sambil digerak-gerak ke } \\
\text { belakang, depan kearah } \\
\text { sudut kanan depan. Lutut } \\
\text { kiri diangkat dua kali kearah } \\
\text { sudut kiri depan kaki kiri } \\
\text { gerak mengikuti kaki kanan } \\
\text { dibelakang, kedua tangan } \\
\text { memegang topeng } \\
\text { digerakan ke belakang- } \\
\text { depan kearah sudut kiri } \\
\text { depan. }\end{array}$ \\
\hline 6 & Kuputarung & & $\begin{array}{l}\text { Kedua lutut ditekuk } \\
\text { kearah } \\
\text { depan, posisi badan } \\
\text { membungkuk arah depan } \\
\text { kedua tangan memegang } \\
\text { topeng, kedua kaki putar ke } \\
\text { kakan, kaki digerakan } \\
\text { bergantian kanan kiri gerak } \\
\text { memutar ke kanan satu } \\
\text { lingkaran, kedua tangan } \\
\text { pegang topeng digerak ke } \\
\text { bawah ke atas dan sebaliknya. }\end{array}$ \\
\hline 7 & Lembean kanan-kiri & & $\begin{array}{l}\text { Barong digigit, posisi kaki } \\
\text { tanjak kanan, tangan kanan- } \\
\text { kiri mentang ke samping } \\
\text { kanan-kiri. Gerak topeng } \\
\text { mengikuti gerakan kaki. }\end{array}$ \\
\hline 8 & Ngindik (kucingan) & $1-8$ & $\begin{array}{lll}\text { Posisi kedua tangan } & \text { seperti } \\
\text { mau mencakar, } & \text { kaki posis } \\
\text { jengkeng kanan } & \text { depan, kiri } \\
\text { belakang } & \text { terus } & \text { maju } \\
\text { bergantian lumak } & \text { sono } \\
\text { jengkeng. } & & \end{array}$ \\
\hline 9 & Enjotan & $1-8 \times 2$ & $\begin{array}{l}\text { Maju kaki kanan enjot, maju } \\
\text { kaki kiri enjot, posisi Barong } \\
\text { mengikuti gerak kaki. }\end{array}$ \\
\hline 10 & Sendalan & $1-8$ & $\begin{array}{l}\text { Kedua tangan digerakan ke } \\
\text { kiri, atas, kanan, bawah; } \\
\text { sambil memegang Barong } \\
\text { dilanjutan putar kanan } \\
\text { Ginjalan }\end{array}$ \\
\hline 10 & Ngasak & $1-8$ & $\begin{array}{l}\text { Kedua kaki gerak loncat } \\
\text { ditempat terus gejoh kaki } \\
\text { kanan, nyendor atas kanan, } \\
\text { loncat mundur kanan } \\
\text { langsung putar nyapu bumi } \\
\text { arah kiri }\end{array}$ \\
\hline 11 & Ngoletan & $1-8$ & $\begin{array}{l}\text { Kaki kiri bertumpu, kaki kanan } \\
\text { diangkat terus badan digerakan } \\
\text { memutar ke arah kanan satu } \\
\text { putaran. Kaki kanan bertumpu, } \\
\text { kaki kiri diangkat terus badan } \\
\text { digerakan memutar ke arah kiri } \\
\text { satu putaran. }\end{array}$ \\
\hline 12 & Jingkrakan & & $\begin{array}{l}\text { Kedua lutut diangkat } \\
\text { bergantian kearah depan, kaki } \\
\text { bergerak naik turun, kedua } \\
\text { tangan memegang topeng } \\
\text { sambil digerakan nak-turun } \\
\text { mengikuti gerakan kaki. }\end{array}$ \\
\hline
\end{tabular}

\section{Proses Pembentukan Pola-Pola Gerak Barongan Kertas}

Proses pembentukan pola-pola gerak Barong kertas diawali dengan observasi, eksplorasi, eksperimen, perenungan, pembentukan, dan pelatihan. 1. Observasi

Observasi dilakukan untuk mengamati terhadap objek dalam hal ini pertunjukan topeng
Barongan Blora dan bentuk topeng. Hal ini dilakukan untuk mendapatkan gambaran terhadap penelitian Pola-Pola Gerak Dalam Topeng Barongan Kertas. Pertama yang dilakukan adalah mengamati topeng antara yang terbuat dari kayu dan yang terbuat dari kertas. Dari sini dapat dilihat bagaimana cara mempermainkan topeng yang terbuat dari kertas. Berbeda dengan topeng terbuat dari kayu lebih memiliki kekuatan dan memiliki berat yang lebih dibanding dengan topeng kertas, maka gerak yang dihasilkan sebanding dengan berat dan bentuk topeng. Melihat kenyataan itu pengamatan berlanjut pada pengamatan Barongan kertas dengan segala bentuk dan kondisi seagai upaya permainan pada pola gerak yang digunakan. Pada pola gerak topeng Barongan kertas lebih menonjolkan pada teknik gerak yang dinams dan permainan topeng untuk mendapatkan karakter sesuai dengan pola-pola geraknya.

\section{Eksplorasi}

Eksplorasi merupakan cara mencari kemungkinan-kemungkinan berdasar data observasi ke dalam sebuah bentuk atau format pertunjukan Barongan Kertas. Data amatan maupun data pustaka sebagai dasar pencarian kemungkinan-kemungkinan model pertunjukan topeng Barongan Kertas yang kemudian diformat dalam bentuk Pola-Pola Gerak Barongan Kertas. Hal ini dapat berubah karena perlu adanya eksperiman. Eksplorasi dilakukan mencari kemungkinan teknik-teknik permainan Barongan Kertas terkait dengan pola gerak beladiri yang distilisasi menjadi sebuah motif gerakdasar Barong. Pertimbangan pencarian atau eksplorasi dilakukan sebagai suatu upaya pembentukan pola gerak dengan mencari pola gerak baku kemudian dilakukan polapola gerak selingan dan variasi geraknya sehingga menjadi gerak yang memiliki sebuah makna yang dikenal dengan motif gerak. Seperti motif gerak ginjalan, sebagai pola dasar gerak kaki menjadi lebih makna dengan selingan gerak tangan dalam hal ini permainan topeng kemudian divariasi dengan gerak yang lain menjadi sebuah motiv gerak ginjalan kupu tarung. Eksplorasi ini sangat pentimg artinya sebagi suatu penjelajahan terhadap kemungkinankemungkinan gerak yang didapat dari permainan Barongan Kertas.

\section{Eksperimen}

Eksperimen merupakan metode berkelanjutan dari metode eksplorasi. Hal ini dilakukan sebagai tahap percobaan dari kemungkinan-kemungkinan pencarian model yang kemudian percobaan itu di dapat suatu 
teknik, pola garap, dan model yang tepat untuk dilakukan perenungan terhadap data yang didapat. Eksperimen yang dilakukan dalam teknik permainan Barogan Kertas sebagai bentuk uji coba terhadap motiv gerak dan kesesuaiannya dengan karakter dan bentuk topeng Barong. Perlu diingat eksperimen menajdi gagal apabila suatu percobaan itu setelah menjadi motiv gerak dirasa kurang cocok dengan karakter Topeng. Solusi yang dilakukan dengan mencoba menambah atau mengurangi gerakan untuk penyesuaian teknik gerak dan karakter.

\section{Perenungan}

Perenungan merupakan metode perenungan sebagai sebuah bentuk telaah kembali terhadap eksplorasi dan eksperimen sebelum penetapan suatu bentuk model pertunjukan Barongan topeng kertas dengan demikian perenungan merupakan beberapa pertimbangan terhadap prototife yang dihasilkan. Maka perlu diperhatikan kondisi masyarakat, model pertunjukan, dan pengguna. Dengan kata lain bagaimana model itu dibuat, dipergunakan, dan dipublikasikan (made used and profesitionpubalication). Perenungan perlu mempertimbangkan tema sebauh garapan tari Barong terkait dengan durasi, tempat pentas, dan event. Perenungan sangat penting sebagai upaya meninjau kembali motiv gerak yang telah didapat dari eksplorasi dan eksperimen sebelum ditetapkan sebagai motif dasar gerak dan mempertimbangkan kemungkinan perkembangan gerak tersebut.

\section{Pembentukan}

Pembentukan, metode ini merupakan tahap akhir sebelum disosialisasikan atau dialihkan. Pembentukan dilakukan setelah memandang dari eksperimen atau percobaan serta perenungan dipandang telah mencapai tujuan yang diinginkan baru menetapkan bentuk-bentuk mulai dari motif gerak, tata busana, panggung, musik tari, pola ceritera yang menyangkut naskah dan skenario telah dianggap sesuai dengan tujuan.

\section{Pelatihan}

Pelatihan merupakan tahap penentu sebelum model pertunjukan dipentaskan maka perlu diakan latihan dan pelatihan ini dimaksudkan bukan sekedar akhir dari suatu pertunjukan melainkan sebagai suatu sosialisasi terhadap model yang dipertunjukan.

\section{DAFTAR PUSTAKA}

Slamet, MD, "Pengaruh Perkembangan Politik Sosial dan Ekonomi Terhadap Barongan Blora 1964-2009" Disertasi untuk memperoleh derajat Doktor pada Sekolah Pascasarjana Program Studi Pengkajian Seni Pertunjukan dan Seni Rupa Universitas Gadjah Mada Yogyakarta 2011.

Barongan Blora Menari di atas Politik dan Terpaanzaman. Surakarta:Citra Sains. 2012.

Karyono,"Model Pertunjukan Barongan Anak", Iaporan Penelitian dibiayai DIPA ISI Surakarta 2012. 